\title{
ANALISA TATA KELOLA TEKNOLOGI INFORMASI MENGGUNAKAN KERANGKA KERJA COBIT DENGAN MODEL MATURITY LEVEL (study kasus Bimbingan belajar Pringsewu)
}

\author{
Kintan Imanita \\ 1611050078 \\ Fakultas Bisnis \& Komputer \\ Institus Informatika \& Bisnis Darmajaya Lampung \\ kintanimanita.1611050078@mail.darmajaya.ac.id
}

\begin{abstract}
Peranan Sistem Informasi/Teknologi Informasi yang sangat signifikan harus diimbangi dengan pengaturan dan penegelolaan yang tepat sehingga kerugian/ancaman yang mungkin terjadi dapat dihindari bahkan mampu dicegah. Pengamatan ini membahas mengenai keefektifan Tata Kelola Teknologi Informasi (TI) pada Bimbingan belajar Pringsewu. Tujuan pengamatan ini adalah mempelajari pengelolaan TI sesuai dengan standar COBIT Framework, membuat rancangan Tata Kelola infrastruktur yang relevan dengan kegiatan operasional Bimbingan belajar Pringsewu sesuai dengan standar COBIT Framework, membangun Tata Kelola TI yang mampu mengimplementasi dan dapat menilai tingkat kematangan. Metode yang digunakan pada pengamatan ini adalah metodologi kualitatif sedangkan metode pengumpulan datanya dilakukan dengan Interview/wawancara dan kuisioner dengan narasumber yang telah ditentukan sesuai dengan domain dan Control Objective yang digunakan. Narasumber audit Tata Kelola TI pada Bimbingan belajar Pringsewu yaitu Pengajar dan Siswa. Metode analisis data dilakukan beberapa tahap, yaitu penentuan domain, penentuan proses kontrol, penentuan indikator dan pemetaan tingkat kematangan. Kesimpulan pengamatan ini adalah sebagian besar penerapan proses COBIT di Bimbingan belajar Pringsewu berada pada level 3, berdasarkan hasil mapping, terdapat 2 proses TI dan 13 detail Control Cbjectives yang harus diperhatikan pada Bimbingan belajar Pringsewu serta tidak semua rekomendasi proses menurut COBIT dapat diterapkan.
\end{abstract}

Kata Kunci : Tata Kelola Teknologi Infromasi, COBIT Framework, Maturity Level 


\section{Pendahuluan}

Peranan TeknologiInformasi

/Sistem Informasi bagi dunia pendidikan sangatlah penting, hal ini menyebabkan meningkatnya peran Teknologi Informasi agar selaras dengan investasi yang telah dikeluarkan, sehingga dibutuhkan perencanaan yang matang serta implementasi yang optimal.

Peranan Sistem Informasi/Te knologi Informasi yang sangat signifikan harus diimbangi dengan pengaturan dan penegelolaan yang tepat sehingga kerugian/ancam an yang mungkin terjadi dapat dihindari bahkan mampu dicegah. Adapun ancaman yang sering terjadi muncul antara lain kasus kehilangan data, kebocoran data, informasi yang tersedia tidak akurat yang disebabkan oleh pemrosesan data yang salah sehingga integritas data tidak dapat dipertahankan, penyalahgunaan peng gunaan komputer, serta pengadaan investasi Teknologi Informasi/Sistem Informasi yang bernilai tinggi namun tidak diimbangi dengan pengembalin nilai yang sesuai.

Bimbingan belajar Pringsew u merupakan suatu bimbingan belajar yang meliputi pelajar SMP dan SMA. Bimbingan belajar Pringsewu belum mempunyai sistem informasi secara online. Prosedur pendaftaran masih dengan cara manual.
Sehubungan dengan hal tersebut, disini akan membahas menengenai perancangan system informasi. Dan kiranya diperlukan sebuah mekanisme audit Sistem Informasi/Teknologi Informasi terhadap pengelolaan dan bagaimana perancangan tata kelolanya yang sesuai di Bimbingan belajar Pringsewu.

Adapun tujuan penelitian ini adalah :

1. Membuat rancangan tata kelola teknologi informasi untuk perusahaan.

2. Untuk mengetahui nilai kematangan (maturity level) perusahaan.

3. Menghasilkan rekomendasi untuk perusahaan kedepan.

\section{Tinjauan Pustaka}

\section{Tata Kelola Teknologi Informasi}

Tata Kelola Teknologi Informasi (IT Governance) menurut ITGI (2007) adalah tanggung jawab dewan direktur dan manajemen eksekutif, yang terdiri atas kepemimpinan, struktur organisasi dan proses yang memastikan bahwa TI perusahaan mendukung dan memperluas strategi dan tujuan perusahaan. Sanyoto Gondodiyoto (2007) menyatakan bahwa tata kelola TI merupakan salah satu bagian terpenting dari kesuksesan penerapan good corporate 


\section{Tugas Besar Individu}

governance. IT Governance

memastikan pengukuran efektifitas

dan efisiensi peningkatan proses

bisnis perusahaan melalui struktur

yang terkait dengan TI menuju ke

arah tujuan strategis perusahaan. Tata

kelola TI (IT Governance)

memadukan best practices proses

perencanaan, pengelolaan, penerapan

pelaksanaan dan pengawasan kinerja

untuk memastikan bahwa TI benar mendukung pencapaian perusahaan.

Menurut Weber (2000) terdapat

berbagai alasan mengapa tata kelola diperlukan bagi sebuah perusahaan, diantaranya:

1. Kerugian akibat kehilangan dat.

Data merupakan asset yang sangat berharga bagi setiap perusahaan. Jika data hilang karena unsur kesengajaan ataupun tanpa kesengajaan akan mengakibatkan kerugian besar bagi perusahaan.

2. Kesalahan dalam pengambilan. keputusan yang dibuat pihak manajemen bisa terbantu dengan adanya bantuan sistem TI. Misalnya penggunaan Decision Support System (DSS) sudah banyak diterapkan di perusahaan untuk membantu pihak manajemen dalam menentukan keputusan/ kebijakan yang harus dijalankan, sehingga keputusan tersebut akan menghasilkan kinerja yang lebih baik dari bagian TI.

3. Risiko kebocoran data. Pengolahan data yang baik akan mengurangi tingkat kebocoran data kepada pihak yang tidak memiliki kepentingan. Kebocoran data diperusahaan bisa diminimalkan dengan cara menerapkan system pengolahan dan dokumentasi data yang benar.

4. Penyalahgunaan komputer. Banyak orang pintar tetapi ada yang menggunakan kepintaran tersebut untuk mengganggu sistem TI pihak lain. Misalnya hacker atau cracker adalah contoh orang pintar yang menyalahgunakan komputer untuk mengganggu system pihak lain.

5. Kerugian akibat kesalahan prose perhitungan.

Kesalahan perhitungan data biasanya terjadi saat terjadi perubahan sistem terkomputerisasi lama ke sistem yang baru. Sangat sulit untuk mengetahui kesalahan perhitungan data akibat pergantian sistem, kalaupun bisa akan membutuhkan waktu yang relatif lama.

6. Tingginya nilai investasi TI. Tatakelola TI yang tidak menerapkan perencanaan yang 


\section{Tugas Besar Individu}

\author{
matang biasanya akan \\ membutuhkan biaya yang besar \\ dan kemungkinan manfaat yang \\ didapat dari investasi tersebut \\ tidak optimal.
}

\section{Kerangka Kerja COBIT}

COBIT (Control Objective for Information and Related Technology) merupakan a set of best practices (framework) bagi pengelolaan teknologi informasi (TI). COBIT disusun oleh The IT Governance Institute (ITGI) dan Information System Audit and Control Association (ISACA), tepatnya dulu disebut Information System Audit and Control Foundation (ISACF) pada tahun 1992. COBIT membantu memenuhi berbagai kebutuhan manajemen dengan menjembatani gap antara resiko bisnis, kebutuhan kendali dan permasalahan teknis. COBITmemberikan panduan melalui sebuah doman dan framework proses serta menyajikan aktivitas dalam sebuah struktur logis dan terkelola. Kaidah penerapan COBIT dibentuk dari konsensus para pakar yang akan membantu dalam mengoptimalkan investasi informasi dan akan memberikan sebuah ukuran ketika terdapat sebuah kesalahan. Aktivitas teknologi informasi pada COBIT 4.1 didefinisikan ke dalam empat domain yaitu Perencanaan dan
Pengorganisasian / Plan and

Organise (PO), Penyampaian

Layanan dan Dukungan / Deliver and Support (DS), serta Pengadaan dan Implementasi / Acquire and Implement (AI), Monitor dan Evaluasi / Monitor and Evaluate (ME). Keempat domain tersebut saling berhubungan. PO menghasilkan arahan terhadap penyampaian solusi (AI) dan penyampaian layanan (DS). AI menghasilkan solusi dan membuatnya menjadi layanan. DS menerima solusi dan membuatnya dapat digunakan oleh user. ME memonitor semua proses untuk memastikan bahwa arahan yang ada telah dilaksanakan/diikuti.

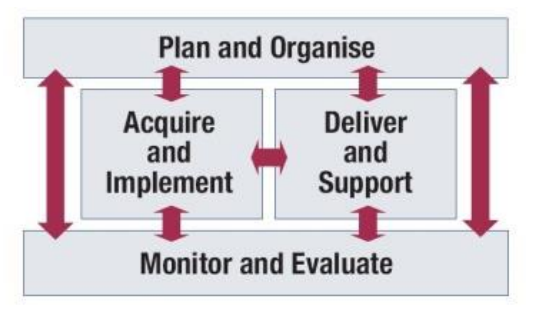

Gambar 1. Empat domain dalam COBIT

Dalam empat domain tersebut, terdapat 34 proses TI yang diidentifikasi oleh COBIT, yang dipakai secara umum. Proses-proses ini dapat digunakan untuk memastikan kelengkapan aktifitas dan tanggung jawab, namun tidak semua proses harus diaplikasikan, dapat pula di kombinasikan, tergantung pada keperluan perusahaan. COBIT juga 


\section{Tugas Besar Individu}

mendefinisikan sasaran kendali untuk setiap 34 proses tersebut. Sasaran kendali TI (IT control objective) merupakan sekumpulan pernyataan atau syarat yang menjadi pertimbangan oleh manajemen untuk mendapatkan control yang efektif terhadap setiap proses TI.

\section{Maturity Level COBIT}

Salah satu alat pengukuran dari kinerja suatu system teknologi informasi adalah model kematangan (maturity level) dari COBIT. Model kematangan untuk pengelolaan dan pengendalian pada proses teknologi informasi didasarkan pada metode evaluasi organisasi sehingga dapat mengevaluasi sendiri dari level tidak ada (0) hingga optimis (5). Model kematangan dimaksudkan untuk mengetahui keberadaan persoalan yang ada dan bagaimana menentukan prioritas peningkatan.

Pendefinisian model kematangan suatu proses teknologi informasi mengacu pada kerangka kerja COBIT secara umum adalah sebagai berikut (ITGI, 2007):

Level 0: non-exixtent. Sama sekali tidak ada proses TI yang diidentifikasi. Perusahaan belum menyadari adanya isu yang akan dibahas

Level 1: initial/ad-hoc. Terdapat bukti yang memperlihatkan perusahaan telah menyadari adanya isu yang perlu dibahas. Tidak ada proses yang baku, sebagai gantinya ada pendekatan khusus yang cenderung diterapkan per kasus. Pendekatan manajemen secara keseluruhan belum terorganisasi.

Level 2: repeatable but intuitive. Proses telah berkembang pada tahap dimana prosedur serupa diikuti oleh orang berbeda yang melakukan tugas yang sama. Tidak ada pelatihan dan komunikasi formal dari prosedur standar, dan tanggung jawab diserahkan kepada individu. Terdapat suatu kepercayaan yang tinggi terhadap pengetahuan dari individu, oleh karena itu kesalahan sering terjadi.

Level 3: defined process. Prosedur telah baku dan telah didokumentasikan,serta dikomunikasi kan melalui pelatihan. Akan tetapi terserah kepada individu untuk mengikuti proses ini, oleh sebab itu penyimpangan akan sulit terdeteksi. Prosedur itu sendiri tidaklah rumit tetapi merupakan formalisasi dari kegiatan yang telah

Level 4: managed and measureable. Manajemen melakukan monitoring dan pengukuran kepatuhan terhadap prosedur dan pengambilan tindakan jika proses yang ada, nampak tidak bekerja secara efektif. Proses dikembangkan 


\section{Tugas Besar Individu}

\begin{abstract}
secara konstan dan`123w memberikan good practice. Otomatisasi dan perangkat pembantu (tools) digunakan secara terbatas atau secara fragmentasi.

Level 5: optimized. Proses mencapai tingkatan bestpractice, sebagai hasil dari peningkatan terusmenerus dan maturity modeling dengan perusahaan lain. Teknologi informasi digunakan secara terintegrasiuntuk mengotomatisasikan workflow menyediakan perangkat pembantu untuk meningkatkan efektivitas dan mutu yang akan membuat perusahaan dapat dengan cepat menyesuaikan diri dengan perubahan.
\end{abstract}

\section{Metode Penelitian}

Metode yang digunakan pada penelitian ini adalah metodologi kualitatif yaitu prosedur penelitian yang menghasilkan data deskriptif berupa kata-kata tertulis atau lisan dari orang-orang dan perilaku yang dapat diamati (Bodgan dan Taylor,1992).

\section{Metode Pengumpulan Data}

Metode pengumpulan data pada penelitian ini adalah metode wawancara adalah metode dimana pengumpulan data dengan cara wawancara atau bertanya langsung kepada pihak yang mengetahui masalah tersebut, pada penelitian ini menggunakan metode kuisioner dengan narasumber yang telah ditentukan sesuai dengan domain dan control objective yang digunakan untuk audit tata kelola Teknologi Informasi pada Bimbingan belajar Pringsewu yaitu pengajar dan siswa.

\section{Metode Analis Data}

Metode analisis data pada penelitian ini dilakukan dengan beberapa tahap, yaitu:

1. Penentuan Domain

Pada tahap ini domain yang akan dievaluasi berdasarkan kebutuhan layanan Teknologi Informasi dari fakultas dengan mengadopsi standar domain yang terdapat dalam kerangka kerja COBIT yaitu Deliver and Support (DS)1 dan Monitor and Evaluate (ME)2.

2. Penentuan Proses Kontrol Pada tahap ini dibuat daftar skala prioritas terhadap proses kontrol yang terdapat dalam masing-masing domain yang telah ditentukan pada tahap sebelumnya. Untuk mendapatka n skala prioritas proses kontrol dibuat kuisioner yang disebarkan kepada narasumber yang ditelah ditentukan. 
3. Penentuan Indikator Kerja

Indikator kinerja mendefinisikan bagaimana proses fungsi

Teknologi Informasi dapat dilaksanakan dengan baik untuk mencapai suatu tujuan. Penentuan indikator berdasarkan control objective dari masingmasing proses kontrol dalam kerangka kerja COBIT.

Pada penelitian ini menggunaka 2 control objective dari 2 domain antara lain:

1. Domain Delivery and Support (DS)

- DS1 Menetapkan dan mengelola tingkat laya nan

2. Domain Monitor and Evaluate (ME)

- ME2 Mengawasi dan megevaluasi control internal.

\section{Pemetaan Tingkat Kematangan}

Pada tahap ini dilakukan pemetaan tingkat kematangan tata kelola Teknologi Informasi di Bimbingan belajar "Bimbel" dengan menggunakan alat ukur model kematangan yang diadopsi dari standar COBIT menggunakan Maturity Level. Data diperoleh dari kuisioner.

\section{Diagram Alir Penelitian}

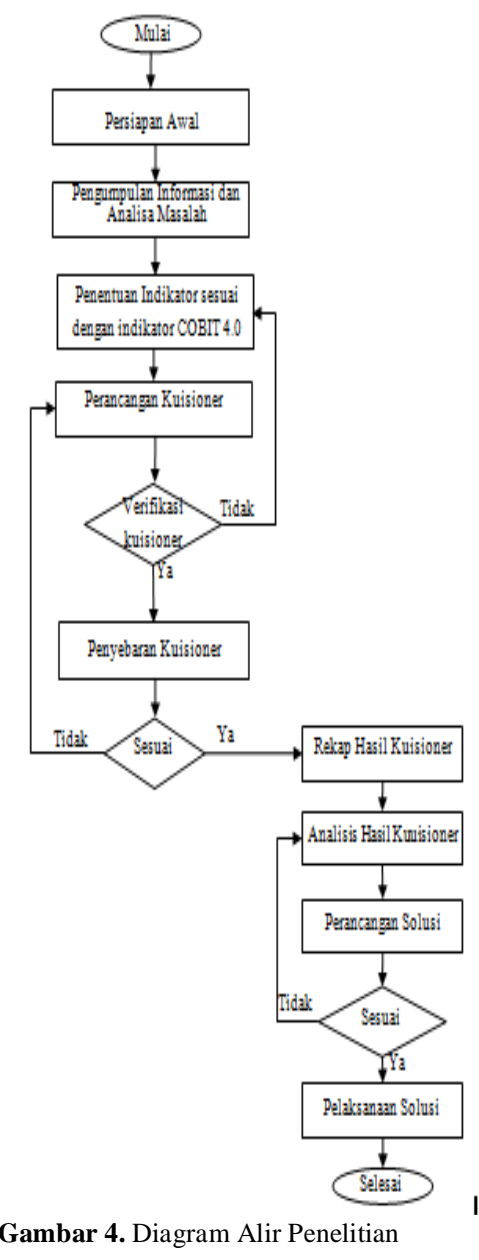

IV. Hasil dan Pembahasan

- Domain Deliver and Support (DS)

Hasil pengamatan untuk domain DS yang menggunakan 1 Control Objektive, yaitu DS1 menghasilkan nilai rata-rata pada level 2.

DS1 : Pada proses ini, yang paling memenuhi adalah level 4 yaitu Manageable and Measure. Tingkat pelayanan di Bimbingan belajar Pringsewu termasuk rendah. Tidak adanya pihak yang bertanggungjawab dalam mengatur 


\section{Tugas Besar Individu}

tingkat pelayanan. Dalam

menentukan tingkat pelayanan belum

dilaksanakan, pelayanan tidak bersifat resmi.

-Domain Monitor and Evaluate (ME)

Hasil pengamatan untuk domain ME yang menggunakan 1 Control

Objektive, yaitu ME2 menghasilkn

nilai rata-rata pada level 3

ME2 : Pengawasan yang dilakukan tidak sesuai dengan standar dan kebijakan, keamanan informasi, kontrol dan perubahan kontrol tidak ditetapkan dalam persetujuan mutu layanan. Tidak adanya peningkatan prosedur dan kebijakan.

Tabel Indeks Maturity tiap proses.

\begin{tabular}{|c|c|c|c|}
\hline \multirow[t]{2}{*}{$\begin{array}{l}\text { Kod } \\
\text { e }\end{array}$} & \multirow[t]{2}{*}{ Objective } & \multicolumn{2}{|l|}{ Nilai } \\
\hline & & Indeks & $\begin{array}{l}\text { Maturity } \\
\text { Level }\end{array}$ \\
\hline DS1 & $\begin{array}{l}\text { Menetapk } \\
\text { an dan } \\
\text { Mengelol } \\
\text { a Tingkat } \\
\text { Layanan }\end{array}$ & 3,14 & 3 \\
\hline $\begin{array}{c}\text { ME } \\
2\end{array}$ & $\begin{array}{l}\text { Mengawa } \\
\text { si dan } \\
\text { Mengeval } \\
\text { uasi } \\
\text { Kontrol } \\
\text { Internal }\end{array}$ & 2,52 & 3 \\
\hline
\end{tabular}

\section{Kesimpulan}

Kesimpulan dari pengamatan ini antara lain:

1. Berdasarkan hasil analisis, data dilihat bahwa sebagian besar penerapan peroses COBIT di Bimbingan belajar Pringsewu berada pada level 3 .

2. Berdasarkan hasil mapping, terdapat 2 IT proses dan 13 detail control objectives yang harus diperhatikan pada Bimbingan belajar Pringsewu.

\section{REFERENCE}

O. M. Febriani and A. S. Putra, "Sistem Informasi Monitoring Inventori Barang Pada Balai Riset Standardisasi Industri Bandar Lampung," J. Inform., vol. 13, no. 1, pp. 90-98, 2014.

[2] A. S. Putra, "Paperplain: Execution Fundamental Create Application With Borland Delphi 7.0 University Of Mitra Indonesia," 2018.

[3] A. S. Putra, "2018 Artikel Struktur Data, Audit Dan Jaringan Komputer," 2018.
A. S. Putra, "ALIAS MANAGER
USED IN
DATABASE
DESKTOP STUDI CASE DB DEMOS." 
[5] A. S. Putra, "COMPREHENSIVE SET OF PROFESSIONAL FOR DISTRIBUTE COMPUTING.”

[6] A. S. Putra, "DATA ORIENTED RECOGNITION IN BORLAND DELPHI 7.0."

[7] A. S. Putra, "EMBARCADERO DELPHI XE 2 IN GPUPOWERED FIREMONKEY APPLICATION.”

[8] A. S. Putra, "HAK ATAS KEKAYAAN INTELEKTUAL DALAM DUNIA TEKNOLOGY BERBASIS REVOLUSI INDUSTRI 4.0.”

[9] A. S. Putra, "IMPLEMENTASI PERATURAN PERUNDANGAN UU. NO 31 TAHUN 2000 TENTANG DESAIN INDUSTRI BERBASIS INFORMATION TECHNOLOGY."

[10] A.

S.

Putra,

"IMPLEMENTATION OF PARADOX DBASE."

[11] A. S. Putra, "IMPLEMENTATION $\mathrm{OF}$ TRADE SECRET CASE STUDY SAMSUNG MOBILE PHONE."

[12] A.

S. Putra, "IMPLEMENTATION PATENT FOR APPLICATION WEB BASED CASE STUDI WWW. PUBLIKLAMPUNG. COM.”
[13] A. S. Putra, "IMPLEMENTATION SYSTEM FIRST TO INVENT IN DIGITALLY INDUSTRY."

[14] A. S. Putra, "MANUAL REPORT $\&$ INTEGRATED DEVELOPMENT ENVIRONMENT BORLAND DELPHI 7.0.”

[15] A. S. Putra, "PATENT AS RELEVAN SUPPORT RESEARCH.”

[16] A. S. Putra, "PATENT FOR RESEARCH STUDY CASE OF APPLE. Inc.”

$\begin{array}{lr}\text { A. S. Putra, } & \text { "PATENT } \\ \text { PROTECTION } & \text { FOR }\end{array}$ APPLICATION INVENT."

[18] A. S. Putra, "QUICK REPORT IN PROPERTY PROGRAMMING."

[19] A. S. Putra, "REVIEW CIRCUIT LAYOUT COMPONENT REQUIREMENT ON ASUS NOTEBOOK."

[20] A. S. Putra, "REVIEW TRADEMARK PATENT FOR INDUSTRIAL TECHNOLOGY BASED 4.0."

[21] A. S. Putra, "TOOLBAR COMPONENT PALLETTE IN OBJECT ORIENTED PROGRAMMING.”

[22] A. S. Putra, "WORKING 


\section{Tugas Besar Individu}

DIRECTORY SET FOR

PARADOX 7."

[23]A. S. Putra, "ZQUERY CONNECTION IMPLEMENTED PROGRAMMING STUDI CASE PT. BANK BCA Tbk."

[24] A. S. Putra, D. R. Aryanti, and I. Hartati, "Metode SAW (Simple Additive Weighting) sebagai Sistem Pendukung Keputusan Guru Berprestasi (Studi Kasus: SMK Global Surya)," in Prosiding Seminar Nasional Darmajaya, 2018, vol. 1, no. 1, pp. 85-97.

[25] A. S. Putra and O. M. Febriani, "Knowledge Management Online Application in PDAM Lampung Province," in Prosiding International conference on Information Technology and Business (ICITB), 2018, pp. 181187.

[26] A. S. Putra, O. M. Febriani, and B. Bachry, "Implementasi Genetic Fuzzy System Untuk Mengidentifikasi Hasil Curian Kendaraan Bermotor Di Polda Lampung," SIMADA (Jurnal Sist. Inf. dan Manaj. Basis Data), vol. 1, no. 1, pp. 21-30, 2018.

[27] A. S. Putra, H. Sukri, and K. Zuhri, "Sistem Monitoring Realtime Jaringan Irigasi Desa (JIDES)
Dengan Konsep Jaringan Sensor Nirkabel," IJEIS (Indonesian J. Electron. Instrum. Syst., vol. 8, no. 2, pp. 221-232.

D. P. Sari, O. M. Febriani, and A. S. Putra, "Perancangan Sistem Informasi SDM Berprestasi pada SD Global Surya," in Prosiding Seminar Nasional Darmajaya, 2018, vol. 1, no. 1, pp. 289-294. 